\title{
Demographic and Clinical Features of Patients with Pediatric Stroke: A Cross-Sectional Study
}

\author{
Pediatrik İnmeli Hastaların Demografik ve Klinik Özellikleri: Kesitsel \\ Bir Çalışma
}

\author{
Basak MANSIZ KAPLAN ${ }^{1}$, Arzu YILMAZ², Meliha SEVIM ${ }^{3}$, Barıs NACIR ${ }^{4}$
}

\begin{abstract}
${ }^{1}$ Ankara Medipol University, School of Health Sciences, Department of Occupational Therapy, Ankara, Turkey
${ }^{2}$ University of Healh Sciences, Ankara Training and Research Hospital, Department of Child Neurology, Ankara, Turkey

${ }^{3}$ University of Healh Sciences, Ankara Training and Research Hospital, Department of Pediatrics, Ankara, Turkey

${ }^{4}$ University of Healh Sciences, Ankara Training and Research Hospital, Department of Physical Medicine and Rehabilitation, Ankara,

Turkey
\end{abstract}

\begin{abstract}
Objective: In the pediatric age group, it is important to detect the risk factors of stroke and diagnose it early, and prevent the recurrence of the disease. This study aimed to conduct a descriptive analysis of demographic and clinical characteristics of pediatric stroke cases in the 0-18 age group and to evaluate the relationship between etiologic causes, risk factors and functional status of these cases.

Material and Methods: The medical files of the patients followed up by the Department of Pediatric Neurology of Ankara Training and Research Hospital were retrospectively examined. Cerebral magnetic resonance imaging and laboratory data were recorded. The Gross Motor Function Classification System, Box and Block Test, Nine-Hole Peg Test were used to evaluate the patients' current functional status.

Results: In 34 pediatric hemiplegic stroke cases, the median age of the onset of symptoms was one year (minimum 0 , maximum 15 years). At the time of evaluation, hemiparesis was found in $73.5 \%$ of the cases and $41.2 \%$ had active seizures. Heterozygous factor $\mathrm{V}$ Leiden mutation was present in $17.6 \%$ of the patients, and homozygous MTHFR (c677c) mutation in 5.9\%. When the etiologic factors were evaluated, there was a mass effect due to venous bleeding in $50 \%$, arterial bleeding in $44.1 \%$, and intracranial bleeding in 5.9\% of the cases. Prophylaxis had been performed in $47.1 \%$ of the patients. There were no significant differences in functional parameters according to thrombophilic risk factors, whether the etiology was of arterial or venous origin, or whether they underwent prophylaxis ( $p>.05)$.

Conclusion: Half of the patients had a stroke of venous origin, and hemiparesis was present in approximately two-third of the cases. Functioning levels seemed to be independent of the presence of etiologic source or thrombophilic risk factors of the disease.
\end{abstract}

Key Words: Cerebral palsy, Hemiplegia, Pediatric age group, Stroke

ÖZ

Amaç: Çocukluk yaş grubunda inme risk faktörlerinin tespit edilerek erken teşhis edilmesi ve hastalığın tekrarının önlenmesi önemlidir. Bu çalışmada, 0-18 yaş grubundaki pediatrik inme olgularının demografik ve klinik özelliklerinin tanımlayıcı

(1)

MANSIZ KAPLAN B

YILMAZA

SEVIM M

NACIRB
0000-0002-1008-9470 :0000-0003-2550-9324 :0000-0002-9948-2972 0000-0002-9163-2569
Conflict of Interest / Çıkar Çatıșması: On behalf of all authors, the corresponding author states that there is no conflict of interest.

Ethics Committee Approval / Etik Kurul Onayı: The study was approved by the Ankara Training and Research Hospital, Clinical Research Ethics Committee, dated 05.12.2019 and number 129.

Contribution of the Authors / Yazarların katkısı: MANSIZ KAPLAN B: Constructing the hypothesis or idea of research and/or article, Planning methodology to reach the Conclusions, Organizing, supervising the course of progress and taking the responsibility of the research/study, Taking responsibility in patient follow-up, collection of relevant biological materials, data management and reporting, execution of the experiments, Taking responsibility in logical interpretation and conclusion of the results, Taking responsibility in necessary literature review for the study, Taking responsibility in the writing of the whole or important parts of the study, Reviewing the article before submission scientifically besides spelling and grammar YILMAZ A: Constructing the hypothesis or idea of research and/or article. Planning methodology to reach the Conclusions, Taking res. M: Planning methodology to reach the Conclusions, Organizing, supervising the course of progress and taking the responsibility of the research/study, Taking responsibility in patient follow-up, collection of relevant biological materials, data management and reporting, execution of the experiments, Taking responsibility in logical interpretation and conclusion of the results, Taking responsibility in necessary literature review for the study. NACIR B: Constructing the hypothesis or idea of research and/or article, Planning methodology to reach the Conclusions, Taking responsibility in necessary literature review for the study, Reviewing the article before submission scientifically besides spelling and grammar. How to cite / Atıf yazım şekli : Mansız Kaplan B, Yılmaz A, Sevim M, Nacır B. Demographic and Clinical Features of Patients with Pediatric Stroke: A Cross-Sectional Study. Turkish J Pediatr Dis 2022;16:93-99.
Correspondence Address / Yazışma Adresi:
Received / Geliş tarihi : 11.01.2021 Accepted / Kabul tarihi : 11.03.2021 Online published Elektronik yayın tarihi DOI: 10.12956/tchd.858272 
bir analizinin yapılması ve bu olguların etiyolojik nedenleri, risk faktörleri ve fonksiyonel durumları arasındaki ilişkinin değerlendirilmesi amaçlanmıştır.

Gereç ve Yöntemler: Ankara Eğitim ve Araştırma Hastanesi Çocuk Nörolojisi Bölümü tarafından takip edilen hastaların tıbbi dosyaları geriye dönük olarak incelendi. Serebral manyetik rezonans görüntüleme ve laboratuvar verileri kaydedildi. Hastaların mevcut fonksiyonel durumunu değerlendirmek için Kaba Motor Fonksiyon Sınıflandırma Sistemi, Kutu ve Blok Testi, Dokuz Delikli Peg Testi kullanıldı.

Bulgular: 34 pediatrik hemiplejik inme vakasında semptomların başlama yașı ortanca bir yıldı (minimum 0, maksimum 15 yıl). Değerlendirme anında olguların \% 73.5' inde hemiparezi bulundu ve \% 41.2' sinde aktif nöbet öyküsü vardı. Hastaların \% 17.6' sında heterozigot faktör V Leiden mutasyonu, \% 5.9' unda homozigot MTHFR (c677c) mutasyonu mevcuttu. Etiyolojik faktörler değerlendirildiğinde olguların \% 50' sinde venöz kanamaya, \% 44.1' inde arteryel kanamaya ve \% 5.9' unda intrakraniyal kanamaya bağlı kitle etkisi vardı. Hastaların \% 47.1' ine profilaksi uygulanmıștı. Trombofilik risk faktörlerine göre, etiyolojinin arteriyel ya da venöz orijinli olmasına göre veya profilaksi uygulanıp uygulanmadığına göre fonksiyonel parametrelerde anlamlı farklllik yoktu ( $p>$.05).

Sonuç: Hastaların yarısında venöz kaynaklı inme vardı ve vakaların yaklaşık üçte ikisinde hemiparezi mevcuttu. İşlevsel düzeyler, hastalığın etiyolojik kaynağı veya trombofilik risk faktörlerinin varlığından bağımsız görünüyordu.

Anahtar Sözcükler: Serebral palsi, Hemipleji, Pediatrik yaş grubu, İnme

\section{INTRODUCTION}

Pediatric stroke is an important cause of neurological morbidity in children. Sensorial and motor deficits, epilepsy, language problems, and behavioral problems can be seen in these children. Although the diagnosis and treatment guidelines are clearer in adults, there may be delays in diagnosis and treatment in pediatric cases due to the lack of clarity concerning childhood stroke $(1,2)$.

Cerebral palsy is a heterogeneous disease of the developing fetus or infant brain, which occurs due to non-progressive damage and affects movement and posture development. There are hemiplegic, diplegic and quadriplegic subtypes of the disease according to motor involvement (3). The most common cause of hemiplegic cerebral palsy is perinatal ischemic stroke. Pediatric strokes have been classified by age. Perinatal stroke is the name of a stroke that occurs between the $20^{\text {th }}$ week of fetal life and $28^{\text {th }}$ postnatal days as a result of the deterioration of cerebral blood flow due to arterial or venous thrombosis. Perinatal stroke has been classified as fetal, neonatal, and presumed (4). Presumed perinatal stroke symptoms are noticeable between 28 days and one year postnatally. The diagnosis of ischemic stroke is made retrospectively by the appearance of chronic infarction on neurological imaging (5). A stroke that develops between the $29^{\text {th }}$ day and 18 years of life is considered as a childhood stroke (6).

Pediatric stroke can have hemorrhagic or ischemic origin with the latter being almost four times more frequent than the former (5). Ischemic strokes are further divided into the subtypes of arterial ischemic stroke and cerebral sinovenous thrombosis $(7,8)$. The causes of pediatric stroke include arteriopathies, cardiac diseases, and thrombophilic factors. The most common cause of perinatal stroke is hypercoagulation. In addition to hypercoagulability, which is inherent in pregnancy, gene mutations, such as factor $V$ Leiden and MTFR may lead to the development of perinatal stroke (6). Although the causes and risk factors of pediatric stroke have been clearly defined in the literature, the number of studies in the literature evaluating these risk factors and functional status is not sufficient. The current study aimed to evaluate the etiologic causes, risk factors, and functional status of patients with pediatric stroke.

\section{MATERIALS and METHODS}

The study was planned prospectively, and approval was obtained from the ethics committee of the the tertiary care hospital. Written consent was obtained from the parents of all children who participated in the study. Patients who were followed up with the diagnosis of pediatric hemiplegia at the Department of Pediatric Neurology of Ankara Training and Research Hospital between June 2018 and 2019 were evaluated. The exclusion criteria were as follows: pain in the upper extremity, severe cognitive impairment, severe visual or auditory problems, history of upper extremity surgery, and a history of botulinum toxin injection into the upper extremity within the last six months.

Cerebral magnetic resonance imaging (MRI) and laboratory data showing the etiologic causes of the patients were retrospectively recorded. The systemic and neurological examinations of all cases were performed. The Gross Motor Function Classification System (GMFCS), Manual Ability Classification System (MACS), Box and Block Test (BBT), and Nine-Hole Peg Test (NHPT) were used to evaluate the patients' current functional status.

GMFCS:First developed for children with cerebral palsy, this system consists of five levels. Level I: Can walk without restriction. Level II: Can walk with restrictions without an assistive device. Level III: Can walk with assistive mobility devices, with restrictions walking outside home and in the community. Level IV: Self-movement is limited, children use powered mobility devices outside home and in the community. Level V: Extremely limited, even with the use of self-help assistive technology $(9,10)$. GMFCS can be applied to children between the ages of 0-18 years (11). 
MACS: This system was developed for children with cerebral palsy to classify their ability to handle objects during their daily activities. It evaluates the participation of both hands in the activities together and cannot evaluate each hand individually. The description of the levels in this system is as follows: Level I: Handles objects easily and successfully. Level II: Handles most objects but with reduced quality or speed of achievement. Level III: Handles objects with difficulty; needs help to prepare or modify activities. Level IV: Handles a limited part of easily managed objects in adapted situations. Level V: Cannot handle objects and has severely limited ability to perform even simple actions. The validity and reliability of this system was previously investigated for children between four and 18 years, and the validity and reliability study of the Turkish version was undertaken by Akpınar et al. $(12,13)$.

BBT: This test is used to evaluate the gross motor function of the upper extremity. It requires a $53.7 \mathrm{~cm} \times 25.4 \mathrm{~cm}$ wooden box consisting of two sections, and 150 blocks with each edge being $2.5 \mathrm{~cm}$. The patient is required to grasp the blocks one by one and pass them from one side of the box to the other The number of blocks passed within one minute determines the score (14). This test can be used in children from three years of age (15).

NHPT: Developed to evaluate the fine motor function of the upper extremity and finger dexterity, this test involves the use of nine pegs with 9-mm width and 32-mm length and nine-hole test material appropriately sized for the pegs. The child is asked to place these pegs into the holes as quickly as possible, and this action is timed. This tool is used from age four. 16 In this study, both BBT and NHPT were repeated three times, and the mean value was calculated. The tests were conducted using only one hand and applied for both upper extremities.

\section{Statistical analysis:}

SPSS v. 17.0 (Chicago Inc., 2008) was used for the statistical analyses. Categorical variables were expressed in frequency (n) and percentages (\%), and continuous variables as a mean, standard deviation, median, minimum and maximum values. Normal distribution was evaluated by visual and statistical methods. Paired groups with normal distribution were analyzed using the independent samples t-test and those without normal distribution were analyzed by the Mann-Whitney $U$ test. The chi-square and Fisher's exact tests were used for the analysis of categorical variables. The presence of correlations was assessed using the Spearman correlation test. Significance level was accepted as $p<0.05$.

\section{RESULTS}

The study was completed with 34 pediatric hemiplegic stroke patients aged 0 to 18 years. The mean age at presentation was
Table I: Demographic and clinical characteristics of pediatric hemiplegic stroke patients.

\begin{tabular}{|c|c|}
\hline Variables & Outcome \\
\hline Age at admission (years) ${ }^{a}$ & $10.2 \pm 5.8(0-18)$ \\
\hline Age of onset of symptoms (years) ${ }^{b}$ & $1(0-15)$ \\
\hline $\begin{array}{l}\text { Age at which rehabilitation started } \\
(\text { years) }\end{array}$ & $2(0.25-15)$ \\
\hline $\begin{array}{l}\text { Gender } \\
\text { Male } \\
\text { Female }\end{array}$ & $\begin{array}{l}23(67.6) \\
11(32.4)\end{array}$ \\
\hline $\begin{array}{l}\text { Presence of kinship between parents } \\
\text { None } \\
\text { Second degree } \\
\text { Third and other degrees }\end{array}$ & $\begin{array}{l}22(64.7) \\
8(23.5) \\
4(11.8)\end{array}$ \\
\hline $\begin{array}{l}\text { Symptoms of admission } \\
\text { Right hemiparesis } \\
\text { Seizures } \\
\text { Left hemiparesis } \\
\text { Loss of consciousness } \\
\text { Others }\end{array}$ & $\begin{array}{l}15(44.1) \\
7(20.6) \\
6(17.6) \\
3(8.8) \\
3(8.8)\end{array}$ \\
\hline $\begin{array}{l}\text { Presence of hemiparesis } \\
\text { None } \\
\text { Yes }\end{array}$ & $\begin{array}{c}9(26.5) \\
25(73.5)\end{array}$ \\
\hline $\begin{array}{l}\text { The presence of epilepsy-seizure } \\
\text { None } \\
\text { Yes }\end{array}$ & $\begin{array}{l}20(58.8) \\
14(41.2)\end{array}$ \\
\hline Laboratory & \\
\hline $\begin{array}{l}\text { Factor } 5 \text { Leiden mutation } \\
\text { Heterozygous } \\
\text { Negative } \\
\text { Not-applicable }\end{array}$ & $\begin{array}{l}6(17.6) \\
21(61.8) \\
7(20.6)\end{array}$ \\
\hline $\begin{array}{l}\text { MTHFR-c677c- mutation } \\
\text { Homozygous } \\
\text { Heterozygous } \\
\text { Negative } \\
\text { Not-applicable }\end{array}$ & $\begin{array}{c}2(5.9) \\
10(29.4) \\
15(44.1) \\
7(20.6)\end{array}$ \\
\hline $\begin{array}{l}\text { MTHFR-a1298c- mutation } \\
\text { Heterozygous } \\
\text { Negative } \\
\text { Not-applicable }\end{array}$ & $\begin{array}{l}11(32.4) \\
15(44.1) \\
8(23.5)\end{array}$ \\
\hline $\begin{array}{l}\text { Etiological factors } \\
\text { Venous } \\
\text { Arterial } \\
\text { Intracranial hemorrhage }\end{array}$ & $\begin{array}{l}17(50.0) \\
15(44.1) \\
2(5.9)\end{array}$ \\
\hline $\begin{array}{l}\text { Prophylaxis application } \\
\text { None } \\
\text { Yes }\end{array}$ & $\begin{array}{l}18(52.9) \\
16(47.1)\end{array}$ \\
\hline
\end{tabular}

a: Mean \pm standard deviation (minimum - maximum), b: Median (minimum - maximum)

$10.2 \pm 5.8$ years, and the median age of the onset of symptoms was one year (minimum 0, maximum 15 years). The median age at the time of the initiation of rehabilitation after diagnosis 
Table II: Analysis of variables according to the presence of hemiparesis.

\begin{tabular}{|c|c|c|c|c|}
\hline & Total $(n=34)$ & Hemiparesis $(n=25)$ & Not-hemiparesis $(n=9)$ & $\mathbf{p}$ \\
\hline $\begin{array}{l}\text { Gender, }{ }^{*} \\
\text { Male } \\
\text { Female }\end{array}$ & $\begin{array}{l}23(67.6) \\
11(32.4)\end{array}$ & $\begin{array}{r}18(72.0) \\
7(28.0)\end{array}$ & $\begin{array}{l}5(55.6) \\
4(44.4)\end{array}$ & .366 \\
\hline $\begin{array}{l}\text { Epilepsy, * } \\
\text { None } \\
\text { Yes }\end{array}$ & $\begin{array}{l}20(58.8) \\
14(41.2)\end{array}$ & $\begin{array}{r}17(68.0) \\
8(32.0)\end{array}$ & $\begin{array}{l}3(33.3) \\
6(66.7)\end{array}$ & $.116^{\dagger}$ \\
\hline $\begin{array}{l}\text { Etiology, * }^{*} \text { Venous } \\
\text { Arterial } \\
\text { ICH }\end{array}$ & $\begin{array}{c}17(50.0) \\
15(44.1) \\
2(5.9)\end{array}$ & $\begin{array}{c}11(44.0) \\
13(52.0) \\
1(4.0)\end{array}$ & $\begin{array}{l}6(66.7) \\
2(22.2) \\
1(11.1)\end{array}$ & $.229^{\ddagger}$ \\
\hline $\begin{array}{l}\text { Prophylaxis, * } \\
\text { None } \\
\text { Yes }\end{array}$ & $\begin{array}{l}18(52.9) \\
16(47.1)\end{array}$ & $\begin{array}{l}13(52.0) \\
12(48.0)\end{array}$ & $\begin{array}{l}5(55.6) \\
4(44.4)\end{array}$ & $.855^{\dagger}$ \\
\hline
\end{tabular}

*: n(\%), t: Fisher's exact test,:: Analysis after controlling intracranial hemorrhage, ICH: Intracranial hemorrhage

Table III: Arterial versus venous origin of etiology and functional status parameters.

\begin{tabular}{|c|c|c|c|c|}
\hline & Total $(n=32)$ & Venous $(n=17)$ & Arterial $(n=15)$ & p \\
\hline $\begin{array}{l}\text { GMFCS, n (\%) } \\
\text { Level I } \\
\text { Level II } \\
\text { Not applicable }\end{array}$ & $\begin{array}{l}11(34.4) \\
13(40.6) \\
8(25.0)\end{array}$ & $\begin{array}{l}8(47.1) \\
4(23.5) \\
5(29.4)\end{array}$ & $\begin{array}{l}3(20.0) \\
9(60.0) \\
3(20.0)\end{array}$ & $.138^{*}$ \\
\hline $\begin{array}{l}\text { MACS, n (\%) } \\
\text { Aged under four } \\
\text { I } \\
\text { II } \\
\text { III } \\
\text { IV } \\
\text { V } \\
\text { Not applicable }\end{array}$ & $\begin{array}{c}3(9.4) \\
4(12.5) \\
3(9.4) \\
8(25.0) \\
3(9.4) \\
3(9.4) \\
8(25.0)\end{array}$ & $\begin{array}{c}1(5.9) \\
4(23.5) \\
1(5.9) \\
4(23.5) \\
0 \\
2(11.8) \\
5(29.4)\end{array}$ & $\begin{array}{c}2(13.3) \\
0 \\
2(13.3) \\
4(26.7) \\
3(20.0) \\
1(6.7) \\
3(20.0)\end{array}$ & $.221^{*}$ \\
\hline BBT (box/min) & $42.0(14.5)$ & $40.3(14.4)$ & 41.8 (15.3) & .825 \\
\hline
\end{tabular}

GMFCS: The Gross Motor Function Classification System, MACS: The Manual Ability Classification System, BBT: The Box and Block Test, NHPT: Nine-Hole Peg Test, *: Fisher's exact test

was two years (minimum 0.25, maximum 15 years). The clinical findings, laboratory data, etiologic factors, and prophylaxis rates of the patients are summarized in Table I.

In the analysis of the variables according to the presence of hemiparesis, no significant difference was found between the presence of hemiparesis and gender and epilepsy $(p>.05)$ (Table II). In the analysis performed excluding two hemiplegic cases due to intracranial hemorrhage, no significant difference was observed between etiologic factors and motor functions when arterial and venous causes of stroke and functional status (GMFCS, MACS, BBT and NHPT scores) were compared ( $p$ $>$.05). Since three of the patients were under 4 years old, they were not evaluated with MACS (Table III). There was no significant difference in functional status according to whether the patients underwent prophylaxis $(p>.05$ for all variables, see Table IV).

No significant correlation was found between the age of the onset of symptoms and functional parameters (GMFCS, MACS, BBT and NHPT scores) except for the presence of a positive correlation between the age of symptom onset and age at the initiation of rehabilitation (Spearman rho $=.543, p=.024$ ). There was no significant difference in the GMFCS, MACS, BBT and NHPT scores according to the presence of thrombophilic causes [factor $V$ Leiden mutation, MTHFR (c677c) mutation and MTHFR (a1298c) mutation] ( $p>$.05).

When the patients were divided into two groups as perinatal stroke $(n=18,53 \%)$ and childhood stroke $(n=16,47 \%)$ and their results were compared, no significant difference was observed between the two groups in terms of the thrombophilic risk factors $(p>$.05). Although there was a difference between etiologic causes, no statistical significance was found (Table V). There was also no significant difference between the two groups concerning the symptoms at presentation $(p>.05)$. Similarly, no significant difference was found in their functional status (GMFCS, MACS, BBT and NHPT scores) ( $p>$.05). The incidence of hemiparesis was calculated as $77.8 \%(n=14)$ in perinatal stroke cases and 75\% $(n=75)$ in childhood stroke cases. 
Table IV: Comparison of the functional status parameters of patients that underwent prophylaxis and those that did not receive this treatment.

\begin{tabular}{|c|c|c|c|c|}
\hline & Total $(n=32)$ & Prophylaxis $(n=15)$ & Not-prophylaxis $(n=17)$ & $\mathbf{p}$ \\
\hline $\begin{array}{l}\text { GMFCS, n (\%) } \\
\text { Level I } \\
\text { Level II } \\
\text { Not applicable }\end{array}$ & $\begin{array}{c}11(34.4) \\
13(40.6) \\
8(25.0)\end{array}$ & $\begin{array}{l}4(26.7) \\
7(46.7) \\
4(26.7)\end{array}$ & $\begin{array}{l}7(41.2) \\
6(35.3) \\
4(23.5)\end{array}$ & $.671^{\star}$ \\
\hline $\begin{array}{l}\text { MACS, } \mathbf{n}(\%) \\
\text { Aged under four } \\
\text { I } \\
\text { II } \\
\text { III } \\
\text { IV } \\
\text { V } \\
\text { Not applicable }\end{array}$ & $\begin{array}{c}3(9.4) \\
4(12.5) \\
3(9.4) \\
8(25.0) \\
3(9.4) \\
3(9.4) \\
8(25.0)\end{array}$ & $\begin{array}{c}2(13.3) \\
1(6.7) \\
0 \\
3(20.0) \\
3(20.0) \\
2(13.3) \\
4(26.7)\end{array}$ & $\begin{array}{c}1(5.9) \\
3(17.6) \\
3(17.6) \\
5(29.4) \\
0 \\
1(5.9) \\
4(23.5)\end{array}$ & $.284^{\star}$ \\
\hline BBT (box/min) & $42.0(14.5)$ & $39.2(14.5)$ & $42.5(10.5)$ & .624 \\
\hline NHPT (second) & $41.5(9.6)$ & 39.7 (10.5) & $42.1(9.2)$ & .593 \\
\hline
\end{tabular}

GMFCS: The Gross Motor Function Classification System, MACS: The Manual Ability Classification System, BBT: The Box and Block Test, NHPT: Nine-Hole Peg Test, *: Fisher's exact test

Table V: Comparison of the thrombophilic risk factors and etiological causes of perinatal stroke and childhood stroke patients.

\begin{tabular}{|c|c|c|c|}
\hline & $\begin{array}{c}\begin{array}{c}\text { Perinatal stroke } \\
n=18\end{array} \\
\end{array}$ & $\begin{array}{c}\text { Childhood stroke } \\
n=16\end{array}$ & $\mathbf{p}$ \\
\hline $\begin{array}{l}\text { Factor } 5 \text { Leiden } \\
\text { Heterozygous } \\
\text { Negative } \\
\text { NA }\end{array}$ & $\begin{array}{c}3(16.7) \\
14(77.8) \\
1(5.6)\end{array}$ & $\begin{array}{l}3(18.8) \\
7(43.8) \\
6(37.5)\end{array}$ & 0.38 \\
\hline $\begin{array}{l}\text { MTHFR-c677c } \\
\text { Heterozygous } \\
\text { Homozygous } \\
\text { Negative } \\
\text { NA }\end{array}$ & $\begin{array}{c}7(38.9) \\
1(5.6) \\
9(50.0) \\
1(5.6)\end{array}$ & $\begin{array}{l}3(18.8) \\
1(6.3) \\
6(37.5) \\
6(37.5)\end{array}$ & 0.39 \\
\hline $\begin{array}{l}\text { MTHFR-a1298c } \\
\text { Heterozygous } \\
\text { Negative } \\
\text { NA }\end{array}$ & $\begin{array}{c}7(38.9) \\
10(55.6) \\
1(5.6)\end{array}$ & $\begin{array}{l}4(25.0) \\
5(31.3) \\
7(43.8)\end{array}$ & 0.59 \\
\hline $\begin{array}{l}\text { Etiology* } \\
\text { Arterial } \\
\text { ICH } \\
\text { Venous }\end{array}$ & $\begin{array}{c}11(61.1) \\
1(0.5) \\
6(33.3) \\
\end{array}$ & $\begin{array}{c}4(25.0) \\
1(6.2) \\
11(68.7) \\
\end{array}$ & 0.06 \\
\hline
\end{tabular}

NA: not applicable, ICH: Intracranial hemorrhage, ": n(\%)

\section{DISCUSSION}

In this study, the etiologic causes, risk factors and functional status of pediatric stroke patients were evaluated. It was concluded that venous or arterial origin or presence of thrombophilic causes did not have an effect on functional status. There was no difference between perinatal stroke and childhood stroke cases in terms of thrombophilic risk factors. Although there was no significant difference between the groups, arterial causes were the most common etiologic factors in perinatal stroke, whereas venous causes were higher in childhood stroke.

In a cohort study evaluating patients with perinatal stroke, it was reported that perinatal arterial stroke was the most common cause (17). Golomb et al.(18) evaluated 22 patients with hemiparesis between two months and eight years of age and found arterial etiology in 22 patients. In another study that included 59 patients aged between 1.3 months and 77 months, arterial etiology was observed more frequently. While venous causes were etiologically determined in 12 patients, 47 patients had arterial etiology (5). In a more recent study, Kitau et al.(19) evaluated 156 patients with hemiplegic cerebral palsy and detected venous etiology at a rate of $60 \%$. This higher rate of venous origin that was first reported in the literature was attributed by the authors to the genetic characteristics of the Japanese population. In the current study, arterial and venous causes were found to be etiologic factors of stroke at the 
rates of $44 \%$ and $50 \%$, respectively. In addition, perinatal and childhood stroke were evaluated separately for the first time, and those of arterial origin were seen more frequently (61\%) in perinatal stroke cases similar to that found in the literature, whereas venous origin was found to be $68.7 \%$ in childhood stroke patients. No significant difference was found between the two groups, but this may be related to the sample size. This finding suggests that the frequency of venous etiologic causes may increase with age. Further studies with more patients can shed more light on this issue.

Prothrombotic factors are risk factors for pediatric stroke, and the literature indicates that they can be seen in $20-50 \%$ of these patients (6). In this study, a total of eight patients were found to have a prothrombotic risk factor, namely heterozygous factor $\checkmark$ Leiden mutation in six and homozygous MTHFR-c677cmutation in two cases. The overall rate of prothrombotic risk factors was $23.5 \%$, which is consistent with the literature.

In the literature, hemiparesis has been reported in 55-61\% of cases with childhood stroke $(6,20)$. For perinatal stroke, this rate is around $58 \%(21,22)$. In this study, the rate of hemiparesis was $77.8 \%$ for perinatal stroke and $75 \%$ for childhood stroke. Compared to the rate reported in the literature, the incidence of hemiparesis was slightly higher in the current study.

Kitai et al. (19) evaluated 156 children with hemiplegic cerebral palsy. Based on the MRI findings, they divided the patients according to the presence of arterial, venous and localized ischemic lesions and reported a difference at the intellectual level and in terms of epilepsy, but they found no difference in functional levels. It was concluded that epilepsy was more common in the presence of periventricular venous infarction. In our study, we observed that venous and arterial etiologic factors did not result in any difference in the functional status of patients. In addition, the presence of arterial or venous involvement did not affect the frequency of epilepsy.

In the literature, there are no studies investigating the relationship between functional status and prothrombotic factors. In our study, these risk factors were not associated with the presence of hemiparesis or that of epilepsy. There was also no significant difference in the functional status of cases with these risk factors.

There were some limitations of our study, with the most important being the small sample size. The reason for this was that the study was a single center study. We included all patients who were followed up and completed the inclusion criteria. This situation resulted in a further decrease in the number of patients when subgroup comparison was made. A reason for the lack of statistical difference in these subgroup analyzes may be the result of the small sample size. Multi-center studies may clarified on this situation. The second limitation concerns the cross-sectional design of the study, which may not have allowed to sufficiently evaluate the effect of etiologic factors and risk factors on the functional status of patients. A prospective cohort study can explain the correlations between these parameters more clearly.

In conclusion, it can be stated that the presence of venous or arterial origin or the presence of thrombophilic causes has no effect on the functional status of pediatric stroke cases. While arterial causes are the most common etiologic factors in patients with perinatal stroke, venous causes are more common in childhood stroke.

\section{REFERENCES}

1. Rafay MF, Pontigon AM, Chiang J, Adams M, Jarvis DA, Silver F et al. Delay to diagnosis in acute pediatric arterial ischemic stroke. Stroke 2009;40:58-64.

2. Gabis LV, Yangala R, Lenn NJ. Time Lag to Diagnosis of Stroke in Children. Pediatrics 2002;110:924-8.

3. Bax M, Goldstein M, Rosenbaum P, Leviyon A, Paneth N, Dan B, et al. Proposed definition and classification of cerebral palsy. Dev Med Child Neurol 2005;47:571-6.

4. Lynch JK, Hirtz DG, DeVeber G, Nelson KB. Report of the National Institute of Neurological Disorders and Stroke Workshop on Perinatal and Childhood Stroke. Pediatrics 2002;109:116-23.

5. Kirton A, deVeber G. Advances in perinatal ischemic stroke. Pediatric neurology 2009;40:205-14.

6. Felling RJ, Sun LR, Maxwell EC, Goldenberg N, Bernard T. Pediatric arterial ischemic stroke: Emidemiology, risk factors, and management. Blood Cells Mol Dis 2017;67:23-33.

7. Fullerton $\mathrm{HJ}, \mathrm{Wu} \mathrm{YW}$, Zhao S, Johnston SC. Risk of stroke in children: ethnic and gender disparities. Neurology 2003;61:18994.

8. Singh R, Cope WP, Zhou Z, De Witt ME, Boockvar JA, Tsiouris AJ. Isolated cortical vein thrombosis: case series. J Neurosurg 2015;123:427-33.

9. Palisano R, Rosenbaum P, Walter S, Russell D, Wood E, Galuppi B. Development and reliability of a system to classify gross motor function in children with cerebral palsy. Dev Med Child Neurol 1997;39:214-23.

10. Palisano RJ, Hanna SE, Rosenbaum PL, Russell DJ, Walter SD, Wood EP, et al. Validation of a model of gross motor function for children with cerebral palsy. Phys Ther 2000;80:974-85.

11. Palisano RJ, Rosenbaum P, Bartlett D, Livingston MH. Content validity of the expanded and revised Gross Motor Function Classification System. Dev Med Child Neurol 2008;50:744-50.

12. Eliasson AC, Krumlinde-Sundholm L, Rösblad B, Beckung E, Arner M, Ohrvall AM, et al. The Manual Ability Classification System (MACS) for children with cerebral palsy: scale development and evidence of validity and reliability. Dev Med Child Neurol 2006;48:549-54.

13. Akpinar P, Tezel CG, Eliasson AC, Icagasioglu A. Reliability and cross-cultural validation of the Turkish version of Manual Ability Classification System (MACS) for children with cerebral palsy. Disabil Rehabil 2010;32:1910-6.

14. Connell LA, Tyson SF. Clinical reality of measuring upper-limp ability in neurologic conditions. A systematic review. Arch Phys Med Rehabil 2012;93: 221-8. 
15. Jongbloed-Pereboom M, Nijhuis-van der Sanden MW, Steenbergen B. Norm scores of the box and block test for children ages 3-10 years. Am J Occup Ther 2013;67:312-8.

16. Poole JL, Burtner PA, Torres TA, McMullen CK, Markham A, Marcum ML, et al. Measuring dexterity in children using the Ninehole Peg Test. J Hand Ther 2005;18:348-51.

17. Wu YW, Lindan CE, Henning LH, Yoshida CK, Fullerton HJ, Ferriero DM, et al. Neuroimaging abnormalities in infants with congenital hemiparesis. Pediatr Neurol 2006;35:191-6.

18. Golomb MR, MacGregor DL, Domi T, Armstrong DC, McCrindle BW, Mayank S, et al. Presumed pre- or perinatal arterial ischemic stroke: risk factors and outcomes. Ann Neurol 2001;50:163-8.
19. Kitai Y, Haginoya K, Hirai S, Onmura K, Ogura K, Inui T, et al. Outcome of hemiplegic cerebral palsy born at term depends on its etiology. Brain Dev 2016;38:267-73.

20. Steinlin M, Roellin K, Schroth G. Long-term follow-up after stroke in childhood. Eur J Pediatr 2004;163:245-50.

21. Grunt S, Mazenauer L, Buerki SE, Boltshauser E, Mori AC, Datta $\mathrm{AN}$, et al. Incidence and outcomes of symptomatic neonatal arterial ischemic stroke. Pediatrics 2015;135:e1220-8.

22. Laugesaar R, Kolk A, Tomberg T, Metsvaht T, Lintrop M, Varendi $\mathrm{H}$, et al. Acutely and retrospectively diagnosed perinatal stroke: a population-based study. Stroke 2007;38:2234-40. 